\title{
ENVIRONMENTAL MANAGEMENT AS POLITICAL SUSTAINABILITY
}

\author{
DAVID L. LEVY \\ University of Massachusetts, Boston
}

Grounded in critical theory and the Gramscian concept of hegemony, this article argues that environmental management (EM) can be understood as an accommodation to growing public awareness of environmental problems that potentially threatens dominant hegemonic coalitions. On the material level, EM is a set of practices that ameliorates the more egregious environmental consequences of industrial production; on the ideological and symbolic level, EM constructs products and companies as "green" and legitimizes the primacy of corporate management's role in addressing environmental problems. EM is thus seen to be more about political than environmental sustainability.

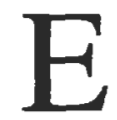

nvironmental management (EM) has grown rapidly in the last few years as an emergent set of managerial practices as well as a new subdiscipline within the academic field of management. EM is critical of traditional business practices that ignore the impact of business activities on the natural environment and that treat the earth as an infinite reserve of natural resources and a bottomless sink for industrial waste (Shrivastava, 1995a; Starik \& Rands, 1995). Proponents of EM argue that by adopting a range of managerial practices that take account of the linkages between business organizations and the environment, sustainable economic growth and environmental goals can be reconciled. This harmony of economic and environmental interests is a foundational assumption of EM; indeed, EM could be defined as the development and implementation of management practices that address environmental goals while furthering private corporate interests (Purser, Park, \& Montuori, 1995).

Although some hail EM as a major step toward environmental sustainability, others disparage it as cynical and tokenistic "greenwashing" that masks business as usual. Radical environmentalists of various stripes tend to dismiss EM as reformist, managerialist incrementalism that ignores the root cause of environmental degradation-though there is considerable disagreement on the question of what is the root cause (Merchant, 1992).

Rather than embrace EM uncritically or dismiss it out of hand, this article engages in a detailed critical analysis of EM as discourse and as practice. After describing EM and existing radical critiques, the article develops the argument that growing public concern about environmental problems threatens the autonomy and market position of dominant corporate interests, and perhaps the legitimacy of the economic system itself. As a theoretical framework, the Gramscian concept of hegemony is used to conceptualize the situation of a historically situated coalition of business, government, professional, and intellectual elites that is at once dominant in society but neither stable nor unchallenged (Cox, 1983; Gramsci, 1988; Sassoon, 
1987). A system of production that generates socially unacceptable levels of environmental degradation could provoke a challenge to this hegemonic coalition because it relies on popular consent and legitimacy.

Within this theoretical context, the article explores EM as an accommodation to this threat. It is argued that EM can be understood as an integrated response on the practical and ideological level that serves to deflect more radical challenges to the hegemonic coalition. In this sense, EM is more about political than environmental sustainability.

On the practical, material level, an examination of EM reveals that it is more than mere greenwashing; although it clearly has its limitations, EM does help to reduce the more flagrant environmental consequences of industrial production. On the ideological and symbolic level, EM serves to construct products and companies as "green" and legitimizes corporate management as the primary societal agent responsible for addressing environmental issues. Together with more overtly political measures, such as forming alliances with environmental organizations, EM helps to shore up the legitimacy of the hegemonic bloc. At the same time, however, corporate adoption of EM practices and discourse can be viewed as concessions in a Gramscian "war of position," opening up new opportunities for environmentalists to pursue their goals. ${ }^{1}$

To investigate the ideological nature of EM, this article employs concepts from critical theory to examine practitioner-oriented as well as more academic texts and articles. In recent years, a growing body of scholarship has applied the tools and concepts of critical theory to organization studies and management in general (e.g., Alvesson \& Willmott, 1992; Clegg, 1990; Deetz, 1992) and to specific management disciplines, such as strategy (Knights \& Morgan, 1991), total quality management (TQM) (Steingard \& Fitzgibbons, 1993), marketing (Morgan, 1992), and human resource management (Steffy \& Grimes, 1992; Townley, 1993). A critical analysis of the EM discourse reveals underlying assumptions and power relations and suggests that the field is not a value-neutral body of knowledge being constructed by objective and disinterested academics and practitioners. Rather, the emerging field is being shaped, or "disciplined," by the preexisting models and ideologies embedded in existing management disciplines, in a manner that prioritizes and universalizes corporate and managerial interests at the expense of consumers, workers, and the broader public (Alvesson, 1991). The ideological character of four central assumptions of EM are discussed: that the environment can and should be managed, that corporate managers should be doing the managing, that EM is a winwin opportunity, and that traditional management functions and concepts are the appropriate tools.

\section{WHAT IS ENVIRONMENTAL MANAGEMENT?}

A number of writers have documented a range of corporate environmental practices that affect all the traditional functional activities of a firm (Dillon \& Fischer, 1992; Fischer \& Schot, 1993; Hansen, 1995; Hansen \& Gleckman, 1994; Hunt \& Auster, 1990; Rappaport \& Flaherty, 1992; Shrivastava, 1992; Starik \& Rands, 1995). These practices include efforts to reduce pollution at its source in the production process, marketing efforts to identify green consumers and develop products tailored to this segment, and the use of life-cycle analysis to assess the full cost and environmental impact of a product from raw material consumption to disposal or recycling. EM may also entail changes in organizational structures and processes, such as the appointment of senior managers with responsibility for 
environmental issues, the institution of annual environmental audits, and the inclusion of environmental performance data in personnel review processes. A set of international standards is under development for corporate EM, ISO 14000 , enabling companies to receive official certification that they are following a set of environmental procedures and processes (Balikov \& Cavanaugh, 1996).

A growing number of business schools are offering EM courses and specializations, and a variety of texts is now available specifically designed for such courses (Birchard, 1994; Buchholz, 1993; Friedman, 1993; Stead \& Stead, 1996). New journals and conferences herald the awakening of academic interest in the field of EM. The more theoretical EM literature attempts to identify and describe paradigms of management according to their orientation toward the natural environment (Clair, Milliman, \& Whelan, 1996; Egri \& Pinfield, 1996; Purser et al., 1995; Rasanen, Merilainen, \& Lovio, 1995). This literature generally critiques traditional management for being mechanistic and anthropocentric and for ignoring environmental constraints and externalities, then proceeds to describe and advocate new paradigms of management that incorporate ecological awareness to various degrees. Shrivastava (1995a) argues for a form of "ecocentric management" that could ensure sustainable economic development and would also embody values such as nonhierarchical and participative organizational forms. Gladwin, Kennelly, and Krause (1995) suggest a "sustaincentric" synthesis of traditional and ecocentric paradigms, which would privilege humans as intelligent stewards of the environment, is not antitechnology, and offers a managerialist approach to limit human economic activity within bounds set by the ecosystem.

More radical critiques suggest that the existing social and economic system is inherently destructive to the environment, and they tend to dismiss EM as reformism that does not go to the root of the problem (Merchant, 1992). These radical critiques do not agree, however, on what the root of the problem is or what changes are needed. Neo-Marxist variants emphasize production for profit under capitalism, with its goals of profit maximization and ever-growing production and consumption, and the ability of corporations to externalize costs and internalize benefits (Daly \& Cobb, 1989; O'Connor, 1989; Pepper, 1993; Schnaiberg \& Gould, 1994). Deep ecologists also provide a critique of modern industrialism but, rather than focus on the political economy of production (who controls production and for whose benefit), argue that the problem lies deep in anthropocentric assumptions that humankind is above and separate from nature and should use technology to control and subdue nature for human benefit (Devall \& Sessions, 1985; Lovelock, 1988; Naess, 1989). Ecofeminism shares with deep ecology a critique of anthropocentrism but points to patriarchy as the key ideology that legitimates male domination over women and nature (Salleh, 1984, 1992).

These "red-green" debates revolve around a number of key issues. Deep ecologists see the problem as primarily deriving from modern Western culture, philosophy, and attitudes. Neo-Marxists retort that these are part of the ideological superstructure that reflects and supports the needs of capital. In other words, industrial capitalism requires and produces a competitive, materialistic society based on wasteful individual consumption (Ewen, 1988; Daly \& Cobb, 1989). Neo-Marxists accuse deep ecologists of lacking an analysis of class and power, and ecofeminists add that both tend to ignore gender. Deep ecologists accuse neo-Marxists of being anthropocentric and harboring modernist ambitions to harness nature for human benefit. Neo-Marxists reply that Marx and Engels both understood the dependence of economic systems on the natural environment (Parsons, 1977) and that ecocentrism is both undesirable in its potential for misanthropism and impos- 
sible in its efforts to assign intrinsic value and moral consideration to nature (Pepper, 1993, p. 4).

Common to radical critiques is the prediction of environmental disaster if fundamental changes are not adopted. Bookchin (cited in Merchant, 1992) has argued that

Our world will either undergo revolutionary changes, so far-reaching in character that humanity will totally transform its social relations and its very conception of life, or it will suffer an apocalypse that may well end humanity's tenure on the planet. (p. 144)

In contrast to this apocalyptic view, it is argued here that capitalism is capable of adapting and responding to environmental challenges by acting on the political, material, and ideological levels. Rather than dismiss EM out of hand as mere tokenism or embrace it as a panacea, we need to understand it as an accommodation that addresses some of the worst environmental excesses while deflecting demands for more radical change.

\section{PUBLIC ENVIRONMENTAL AWARENESS AS A CHALLENGE TO HEGEMONY}

The concept of hegemony is elaborated here to understand the nature of the threat posed by the environmental crisis and how EM can be viewed as an accommodation to this threat. Gramsci (1988) used the term hegemony to connote a congruence of material and ideological forces that enables a coalition of interests to maintain a dominant position in society. This coalition is a "historic bloc" that reflects a historically situated political constellation that transcends any one class (Cox, 1983; Gill, 1990; Gramsci, 1988). Hegemony is secured through material control over economic resources as well as ideological control over symbols, imagery, and modes of thought. In achieving and sustaining hegemony, Gramsci emphasized the process of consent and compromise rather than coercion; the role of ideology is crucial in this process of achieving consent. In contrast with more materialist Marxist orientations, Gramsci did not see the ideological superstructure as being driven in a deterministic way by the economic base (the relations of production); rather, the ideological realm, encompassing discursive and symbolic aspects embedded in modes of thought and institutions, has its own effectivity and is consequently also a site of political struggle.

Hegemony, in this view, is neither total nor stable; it is riven by contradictions, conflicting interests, and shifting alliances. There are always some groups who stand outside of the dominant ideology but lack the political strength to challenge the hegemonic bloc. At the same time, the dominant coalition does not have total power over state institutions. Influence over governmental agencies is at least contested by consumer groups, environmentalists, and organized labor; although some agencies, such as the U.S. Department of Energy, might appear to be captured by industry, others, such as the Environmental Protection Agency (EPA), are more able to exert a significant constraint on corporate action. ${ }^{2}$

It has long been recognized that environmental pollution and resource depletion are by-products of industrial production. Economists often refer to environmental costs as the archetypal negative externality that firms fail to take into account in their decision making (Stavins, 1989). Even business texts affirm that, at least until recently, it has been the conventional wisdom that business and the environment 
are not particularly harmonious interests (Buchholz, 1993, p. 53). Until the 1980s, however, the common perception that business did not care for the environment was, at worst, a minor contradiction in the economic and political system. Most environmental concerns were limited and generally local or regional in scope. The wave of environmental activism in the 1960s and 1970s, originating with the publication of Carson's Silent Spring in 1962, was accommodated in the United States by the establishment of the EPA and the issuance of a number of regulations to address air, water, and land pollution. Business acquiesced in this compromise partly because federal regulation could preempt a patchwork of varied and sometimes stricter state laws that would have been even costlier to meet (Hoffman, 1996, p. 12). The more activist and radical elements of the environmentalist movement could safely be marginalized, although they did enjoy considerable success in constraining the nuclear power industry.

By the latter 1970 s, the broader challenge to hegemony from radical students, antiwar, and other groups had dissipated. Business interests were able to exert sufficient unity to restrain further expansion of state regulatory agencies and defeat a proposal to establish a Consumer Protection Agency (Akard, 1992). Nevertheless, public environmental awareness and concern continued to grow. A Roper survey revealed that the environment was the only area in which public confidence in business declined from 1978 to 1988 (cited in Lehne, 1993). Schot and Fischer (1993) have observed that "industry has found that its environmental performance is under increasing public scrutiny. Caught in a tide of rising expectations, industry is experiencing something of a crisis of credibility and faces considerable public mistrust" (p. 20). A vice president of Hill and Knowlton, a major public relations (PR) firm, put it a bit more bluntly: "The big corporations, our clients, are scared shitless of the environmental movement" (cited in Dowie, 1995, p. 53).

The emergence of global environmental concerns such as ozone depletion and climate change has presented business with the threat of coordinated international action that could cause serious disruption to markets (Haas, Keohane, \& Levy, 1993; Rowlands, 1995). For example, controls on carbon emissions, which are being considered under the current UN-sponsored climate change negotiations, would significantly cut the value of oil and coal-based investments in the energy and transportation sectors, raise costs for energy-intense industries, and provide opportunities for renewable energy companies to challenge the dominance of oil and coal interests (Mansley, 1995).

In Gramscian terms, this could be considered a crisis of hegemony in which the existing dominant coalition of interests is threatened; business faces a realignment of interests that threatens powerful sectors with a loss of autonomy, influence, and market position. On the political level, the threat extends well beyond conventional environmental advocacy organizations. Elements of the scientific community, international organizations such as the United Nations Environmental Programme, and governmental agencies such as the U.S. EPA would all gain power and influence because of the growing resources and attention being focused on environmental problems. Unlikely tactical coalitions sometimes form around particular issues. Boehmer-Christiansen (1995) has discussed how Margaret Thatcher took advantage of the climate change issue to attack the British mine workers' union and undermine European Union institutions by forging an alliance with UN environmental bureaucracies, the scientific community, and corporate gas and nuclear energy interests. Despite Thatcher's general probusiness orientation, the long-term effect of this strategy is likely to be a significant strengthening of the bloc advocating international controls on carbon emissions. 


\section{ENVIRONMENTAL MANAGEMENT AS POLITICAL SUSTAINABILITY}

EM can be understood as a political, practical, and ideological response that accommodates this threat to corporate hegemony. Viewed this way, it is primarily concerned with political rather than environmental sustainability. In contrast to Marxists who argue that a fundamental contradiction between the conditions of capitalist production and the environment will strengthen radical social movements and transform society (O'Connor, 1989), the view taken here is that capitalism is resilient and adaptive; corporations will accommodate the environmental challenge through compromise and co-option, ameliorating their environmental impact sufficiently to blunt serious challenge to their hegemonic position. Luke (1995) has suggested that state agencies will facilitate this process: "In a bid to avoid major social transformations, like those foreseen by radical democratic populists, established state bureaucracies can organize their own 'greening' "' (p. 246).

The political role of EM can also be located theoretically in the context of Habermas's notion of a "crisis of legitimacy." Habermas (1976, 1984b) argued that capitalism is buttressed and legitimized by a liberal ideology that proffers freedom, democracy, prosperity, and equal opportunity. A crisis of legitimation can ensue if this ideology becomes untenable in light of the inequities of capitalism and the growing unwillingness of the private sector to finance state provision of social goods. Extending this idea to the environment, the growth of public concerns about environmental degradation combined with a decline in the public sector's ability and will to address these problems could trigger such a crisis. ${ }^{3}$ EM could forestall such a crisis by curbing the more egregious environmental impacts of industry on a practical level and by constructing corporations as responsible and green on the ideological level.

The more overtly political corporate responses to such threats include increasing political campaign contributions and lobbying against environmental legislation, forging alliances and partnerships with mainstream environmental organizations as well as with government agencies, and the formation of new business associations to address specific issues, such as the Global Climate Coalition to represent fossil fuel interests in international negotiations (Clawson, Neustadtl, \& Scott, 1992; Donahue, 1990; Dowie, 1995; Getz, 1993; Ikwue \& Skea, 1994; Mahon \& Kelley, 1990; Rowell, 1996). Sophisticated lobbying tactics include the mobilization of letters and telephone calls to legislators from corporate-funded shell grassroots groups, a tactic labeled astroturf organizing by the industry itself (Stauber \& Rampton, 1995). The management of environmentalists is a central component of EM, as argued by Elkington (1994): "A key challenge for business in the 1990s will be to convert some of its most critical stakeholders, such as campaigning environmentalists, into a new form of 'customer' " (p. 97). Measures to draw mainstream environmental organizations into the hegemonic coalition include environmental philanthropy, interlocking board memberships, and joint projects such as the Environmental Defense Fund-McDonalds program to reduce waste. PR companies such as the E. Bruce Harrison Company offer integrated services in this field to their corporate clients (Harrison, 1993).

\section{Environmental Management as Practice}

EM is much more than ideological greenwashing that masks production and pollution as usual, as some critiques would portray it (Doyle, 1991; Stauber \& 
Rampton, 1995). Although EM will not produce the kind of "ecotopia" that some radical ecologists might desire, it does have the potential to curb environmental impacts sufficiently so that life for the majority will at least be tolerable and those wanting more radical change will be politically isolated.

Large corporations clearly do possess substantial technological, financial, and organizational resources that could be allocated to addressing environmental problems (Hansen, 1995). Examples abound of successful efforts to curb environmental hazards when businesses are pushed to do so (Dielman \& deHoo, 1993; Smart, 1992). Perhaps the broadest indicator is the success of the EPA's $33 / 50$ program, in which a large group of companies is expected to surpass the target of cutting their emissions of a defined group of hazardous chemicals by $50 \%$ by 1995 from a 1988 baseline (EPA, 1995). The response of industry to the threat of ozone depletion is a more specific example of the rapidity of innovation possible when firms are forced to find a substitute for a particular substance. ${ }^{4}$ Despite the usual pleas from producers and users of chlorofluorocarbon (CFC) gases that substitutes would not work or would be too expensive, substitute products and processes were rapidly developed. Indeed, the electronics industry found that water-based cleaning was actually less expensive than using CFCs (Rothenberg \& Maxwell, 1995).

Traditional management disciplines do have the potential for contributing to this process. The field of environmental accounting has developed and refined the concept and methodology of full-cost accounting, which attempts to assess all the costs associated with a process or product, including costs of storage, disposal, and insurance. There is evidence that companies have not been particularly accurate in estimating even the full private costs of hazardous activities (Rappaport \& Flaherty, 1992; White, 1993; White, Becker, \& Savage, 1993). More ambitious versions of full-cost accounting, particularly life-cycle analysis, attempt to capture the private and social costs of a product from raw material extraction to disposal (Friedman, 1993, p. 31). Despite the well-known difficulties in quantifying such costs, the application of life-cycle analysis is likely to reveal many cases in which companies can profit from cutting resource use or disposal costs.

The application of TQM and, more broadly, lean production concepts offers another example. The message of TQM is that it is often simpler and cheaper to design production processes and products with the environment in mind from the outset rather than add expensive fixes later on. TQM also emphasizes the potential for applying the expertise of production workers and engineers to the task of continuously improving the production process (Rooney, 1993). The prior existence of the TQM discourse in the production and operations management field has helped to accelerate the application of these techniques to environmental problems.

The limits of EM practices must also be acknowledged. It is axiomatic that corporate EM is constrained by organizational self-interest (Purser et al., 1995); private companies will not take steps entailing significant net costs unless forced to do so by regulation. Thus, the proponents of EM enthusiastically make the case that being green is good for business: the win-win scenario. In the EM paradigm, the best firms are those aggressive and proactive in seeking profitable opportunities to reduce emissions or to develop new markets for green products.

The considerable difficulty in quantifying the benefits of improved environmental performance, does, however, provide managers with some degree of discretion (Hoffman, 1996; White et al., 1993). For example, it would be impossible to calculate the return on investment with any level of accuracy for a firm's decision to cooperate with the EPA's voluntary $33 / 50$ program, which not only would reduce 
disposal, insurance, and liability costs but might also improve a company's image and relationships with regulatory authorities and environmental activists.

Given this discretion and a degree of organizational inertia, it is not surprising that substantial variation exists in the extent to which firms embrace EM and incorporate environmental considerations into their operations and functional activities. Some of this variation is systematically associated with the type of industry, the technological and economic viability of substitute products and processes, and national differences in culture, regulations, and institutions (Dillon \& Fischer, 1992; United Nations Transnational Corporations and Management Division, 1993). Some of the variation can be attributed to differences in management values and strategies (Clair et al., 1996; Hunt \& Auster, 1990; Shrivastava, 1992). This suggests that significant incremental improvements to the environment can be obtained from the institutionalization and diffusion of EM practices (Cebon, 1993; Gladwin, 1993; Hoffman, 1996; Jennings \& Zandbergen, 1995).

The diffusion of EM practices is limited, however, by the availability and awareness of win-win opportunities. The empirical evidence on win-win is quite mixed. There are a few well-publicized instances in which reducing pollution has substantially reduced costs. Chevron, DuPont, ARCO, Dow, and $3 \mathrm{M}$ are often cited as enlightened companies moving "beyond compliance" (Friedman, 1993, p. 21; Smart, 1992). There are also several statistical studies linking good environmental performance to financial performance (Hart \& Ahuja, 1996; Russo \& Fouts, in press). But other statistical studies find no relation between environmental and financial performance (Levy, 1995). In fact, most research still shows that corporate efforts are motivated primarily by regulatory and public pressure rather than opportunities for profit (Ashford, 1993; Dillon \& Fischer, 1992; Rappaport \& Flaherty, 1992).

Although some win-win opportunities undoubtedly exist, incremental reductions in emissions are likely to become technically more difficult and expensive (Ashford, 1993; Hart, 1994; Hart \& Ahuja, 1996; Rooney, 1993; Walley \& Whitehead, 1994). The large investments needed in research and development in fields such as renewable energy are often viewed as too risky and actually threaten the market position of companies with substantial investments and assets in existing products and technologies. The limitations of win-win are acknowledged by Buchholz (1993):

Pollution control equipment is expensive to buy and operate. ... Proper disposal of toxic wastes in landfills can be very costly and time consuming. These efforts cut into profits, and in a competitive system, companies that go very far in this direction will simply price themselves out of the market. (p. 55)

This view is echoed by two consultants in McKinsey's EM group: "win-win situations ... are very rare and will likely be overshadowed by the total cost of a company's environmental program" (Walley \& Whitehead, 1994, p. 46).

Relying on consumer preferences for green products is also a dubious approach to solving environmental problems; many environmentalists point out that consumption itself is a major part of the environmental problem. At best, green products appear to be high-priced niche markets. Even if people want to be green consumers, it is unrealistic to expect them to have sufficient information about the life-cycle environmental effects of a myriad purchases. This consumer confusion can, of course, be used to the advantage of the marketer (Coddington, 1993, p. 92). 
EM is limited in that its focus is the individual corporation rather than the complex organization-ecosystem interface. Hart (1995) acknowledges that "there appear to be limits to an exclusively internal (competitive) strategy for sustainable development. Few companies have the capacity or market power to alter unilaterally entire sociotechnical systems" (p. 1003). EM does not adequately address global commons issues, such as ozone depletion, which require collective decisions and action at an international level. At best, EM enhances corporate responsiveness to regulatory and market pressures, but it contains no mechanisms to ensure that human impacts on the environment, in aggregate, are reduced to some acceptable and sustainable level. It is arrogant and somewhat dangerous to think that EM techniques can be simply extended from specific production processes to the global ecosystem. The environment-organization relationship is complex, dynamic, and nonlinear, in which one cannot know the systemwide effects of a small change in one variable (Levy, 1994). The possibility that the growth of industrial activity could have unpredictable and even catastrophic consequences on the global climate system has now been recognized by an international panel of scientists convened by the United Nations (Intergovernmental Panel on Climate Change, 1995).

\section{Environmental Management as Ideology: The Production of Greenness}

EM can also be understood as a discourse layered with ideological significance. Alvesson (1991) defines ideology as "as a relatively coherent set of assumptions, beliefs and values about a demarcated part of social reality, being illuminated in a selective and legitimizing way, restricting autonomous and critical reflection and sometimes favouring sectional interests" (p. 209). As a narrative, EM tells a reassuring story of redemption and enlightenment. The story begins in the dark ages, when unwitting corporations polluted the earth with abandon. The narrative then moves on to a period of enlightenment, when, fueled by new technologies and a broader understanding of ecosystem interdependencies, a few brave pioneer corporations learn that being green is really good for business. This new wisdom is spread until corporations everywhere become enlightened stewards of the environment, dedicating their substantial resources to achieving the goal of sustainable growth.

This story reappears in many of the environmental texts. Friedman (1993) tells it thus:

There is little question that U.S. industry in the past has been guilty of serious environmental depredations, some of them quite dramatic. But most of us, whether in industry, citizen organizations, or government, are wiser today than we were in the past. We have had our consciousness raised. ... Many executives today grew up with an environmental ethic or have adopted the values such an ethic implies. Economic concerns and shareholder and customer demands require that business give environmental issues a high priority. (p. 6)

The discourse of EM can be interpreted as an effort to respond to the hegemonic challenge on an ideological level. This ideology is represented in the taken-forgranted assumptions and modes of thought embodied in the discourse of EM, as it is practiced and taught. The ideology is also actively promulgated by companies in PR efforts as a conscious component of their EM strategies (Strelow, 1992). This PR attempts to construct the company as green and responsible, and its products as 
environmentally friendly. Environmental issues, and environmentalism itself, are framed in ways that do not threaten the autonomy, markets, or assets of the companies involved. One of the more perceptive writers on environmental marketing explicitly exhorts business to be more active in the production of green ideology:

\begin{abstract}
Business leaders must now get actively involved in defining and managing the process of environmental communications. Failure to do so will increasingly pose the risk of their companies' real present (and potential future) value being challenged; their position as a responsible corporate citizen being undermined; and competitive advantage draining away as customers and consumers tum to others who are-or are seen to be-more environmentally responsible. (Elkington, 1994, p. 97)
\end{abstract}

Business leaders appear to have paid good heed this advice. Companies donate substantial sums to environmental causes, develop partnerships with environmental groups, attempt to discredit activist environmentalists as hysterical extremists, and create front organizations with benign-sounding names (Dadd \& Carothers, 1991; Gelbspan, 1995; Helvarg, 1994; Rowell, 1996; Stauber \& Rampton, 1995). A number of larger companies and industry associations produce environmental education kits for classroom use, including videos, posters, activities, and reading packages (Consumers Union, 1995). Dowie (1995, p. 85) estimated that in 1990, corporations spent $\$ 500$ million in environment-related PR.

As an example of a well-coordinated issue-based effort, the environmental organization Ozone Action has documented the activities of a group called the Information Council for the Environment (ICE), formed in 1991 by coal, oil, and utility interests to "reposition global warming as theory, not fact" (Ozone Action, 1996). ICE developed a sophisticated print and radio media campaign directed at particular segments of the population and set up a Science Advisory Panel that included scientists who received substantial funding from the same industries.

One interpretation of this symbolic production activity is to view it as an effort to commodify greenness as a valuable veneer that can be grafted onto products and the company itself. Green products can sell for premium prices, and companies with green images, such as the cosmetic company The Body Shop, have achieved remarkable growth and profitability. The commodification of symbolic value is a concept developed by Baudrillard (1983b), who argued that the basis of value in a capitalist economy "moves from the production of 'useful' goods and services to the generation of semiotic codes and images" (Luke, 1991, p. 348). Ewen (1988) has discussed how advertising creates and sustains the value invested in the image and style of a product and how this superficial value eclipses the functionality of the product itself. There is clearly more to this than identifying green market opportunities; it entails making the symbolism of green a valuable commodity in itself, with which products (and services) can then be wrapped and packaged. Unlike other symbolic values, however, such as status and prestige, greenness is relatively new and unknown in the marketplace. Greenness itself, therefore, needs to be constructed as a valuable symbolic commodity, for example, by associating the term with positive notions such as caring, concern, and responsibility. Consumers might then buy green products because they want to view themselves (and want others to view them) this way. Green products and advertising are thus not just a reaction to a consumer trend but actively constitute a new market segment by symbolically constructing green consumers. 
The production of symbolic imagery and codes has a number of effects that serve to deflect threats to the hegemony of corporate interests. Ewen (1988) argues that the emphasis on symbols "encourages a comprehension of the world that focuses on its easily manipulated surfaces, while other meanings vanish to all but the critical eye. Most notably, as the evanescent becomes increasingly 'real,' reality becomes increasingly evanescent" (p. 262). Baudrillard (1983b) has developed the concepts of simulation and hyperreality to express this blurring of image and reality, in which signs refer to other signs and lose touch with a material foundation: "No longer duplicity or counterfeit, simulation acquires total integrity, actually becoming what is considered the real" (Luke, 1991, p. 362).

There is a sense in which the green corporation is a simulation created in a self-referential circle of symbols. A green corporation is one that markets green products to green consumers; green consumers are constituted through their consumption of green products and images, and the products are green because they are sold by green companies to green consumers. A green company practices EM and is hailed in the media and academic literature for doing so. EM, in turn, is the set of practices that green companies perform. Companies can be officially certified that they are practicing EM by passing the ISO 14000 certification process; to be certified in this way, a company needs to document that it conforms to a self-defined set of procedures and practices.

To the extent that green imagery eclipses a more grounded understanding of environmental issues, companies might find it easier and cheaper to construct themselves and their products as green rather than undertake expensive and risky investments in equipment and processes to reduce environmental impacts-a practice labeled greenwashing by environmental activists (Stauber \& Rampton, 1995). ${ }^{5}$ More broadly, the risks of environmental problems can be minimized in public discourse, reducing the threat of stricter governmental regulation. Buying environmentally friendly products from responsible, green companies can be portrayed as the optimal environmental solution (Dadd \& Carothers, 1991). Challenges to claims of greenness become difficult to sustain as objectivity seems to fade into the swirling fog of symbols and rhetoric; the recent controversy over the environmental performance of The Body Shop illustrates this well (Entine, 1995). If business did fear that environmental issues could contribute to a Habermasian crisis of legitimation, the blurring of image and reality and the manipulation of green symbolism would offer opportunities to contain and manage any such crisis. The very superficiality of imagery forestalls examination of any deeper structural contradictions between business and the environment. As Ewen (1988) expresses it, imagery, or style, "is capable of holding two contradictory ideas simultaneously without any apparent conflict or opposition" (p. 262).

Understanding ideological hegemony requires an analysis of the political economy of symbolic production. In contrast to Baudrillard's (1987) position that power disappears in a hyperreal circulation of signs, ${ }^{6}$ an analysis of corporate environmentalism reveals the presence of economic and political forces prepared to devote considerable resources to shape the "meaning of greening" to suit their own interests. As Luke (1991) puts it, "Power in hyperreality derives from controlling the means of simulation, dominating the codes of representation, and managing the signs of meaning that constitute what hyperreality is taken as being at any particular time" (p. 362).

This is not to suggest that this power is absolute or deterministic; hegemony is neither total nor uncontested. Public concern for environmental degradation stubbornly refuses to disappear; reports of environmental problems from oil spills to 
ozone depletion still receive substantial media attention, and environmental organizations such as the Council on Economic Priorities track chemical emissions and regulatory compliance of leading companies and use the data to develop ranking systems for corporate environmental performance. Financial companies such as Franklin Research use these measures to screen companies for green investment funds. ${ }^{7}$ The Toxic Release Inventory (TRI) reporting requirements for hazardous chemical emissions is still a vital source of information for environmental activists and for the EPA's $33 / 50$ program, despite efforts by the U.S. chemical industry to repeal TRI reporting regulations.

The mere existence of these alternative sources of information does not, however, support the pluralist model of a free and fair marketplace of ideas or a Habermasian (1984a) ideal of unbiased communication. Dissenting voices tend to lack the resources and organization needed to prevail in the political struggle for ideological and symbolic hegemony. Industries, for their part, do not need total ideological control to protect themselves against perceived threats to their interests. To thwart impending regulation, for example, it is often sufficient to create the impression of dissent in the scientific community; this appears to be a tactic effectively used by the oil, coal, and transportation industries in the case of global warming (Ehrlich \& Ehrlich, 1996). Rather than cause reality to disappear in a hyperreal world of simulations, conflicting claims about environmental effects might simply generate enough confusion to quiet the public and provide cover for politicians apprehensive of alienating corporate supporters.

\section{Ideological Assumptions Embedded in EM}

In addition to the more active efforts to construct green products and corporations discussed above, critical theory suggests that a number of ideology-laden assumptions are embedded in the EM discourse. An extensive survey of the growing academic and practitioner-oriented EM literature revealed four recurrent themes that legitimize and entrench the primary role of corporate management in addressing environmental problems.

\section{THE ENVIRONMENT CAN AND SHOULD BE MANAGED}

Implicit in the application of traditional management disciplines to environmental problems - indeed, in the very term environmental management-is the assumption that the natural environment can be managed. As Buchholz (1993) puts it, "The leaders of business and industry, as well as government and educational institutions, need to think in terms of managing nature, managing planet Earth, and taking responsibility for nature to assure the survival of the world" (p. 20). Luke (1995) has noted that the new symbolism of the earth as viewed from space conveys not only a sense of awe and fragility but also "an iconic representation of the world's biggest managerial challenge" (p. 272). Although some environmentalists might argue that managing nature is an oxymoron-nature is, by definition, what is unmanaged-Buchholz argues that we have no alternative but to manage the environment, drawing on McKibben's (1989) observation that human activity is so extensive that "nature" no longer exists.

The physical limitations of the EM paradigm and the dangers of extending it to the management of planet Earth were discussed earlier. It is the ideological implications of assuming that the global ecosystem can be managed that are germane here. The assumption that science can and should be applied to the understanding 
and control of complex ecosystems has deep roots in the modernist paradigm founded on notions of anthropocentric positivist science (Egri \& Pinfield, 1996). The optimistic confidence in scientific progress carries the reassuring message that the environmental side effects of industrial capitalism can be managed, enabling economic growth to continue indefinitely. This ideological function of science has been noted by Dickson (1984):

The projection of confidence in science and scientific "progress" as a cultural belief has, at various strategic points in both European and Amcrican history, been used to help secure the structural changes capitalist society has periodically undergone to escape economic collapse, while masking the social costs that these structural changes have imposed. (p. 8)

One corollary to a faith in scientific understanding of environmental systems is that there is no need to fear events that science has not measured and modeled. This approach has been used quite explicitly in corporate media campaigns against regulations, in what Dickson (1984) calls "an attempt to establish a semantic framework that would help legitimize the anti-regulation campaign by expressing its objectives in the apparently neutral languages of science and common sense" (p. 279).

The application of EM to ensure continued economic growth is an example of what Habermas (1984a) has termed the dominance of a technical rationality that emphasizes the scientific and managerial means of mitigating environmental effects without questioning the goal of increased production and consumption. The primacy of technical rationality leads to discursive closure, inhibiting an open public discussion of the social, aesthetic, and ethical dimensions of environmental impacts and alternative paths to addressing them. As discussed below, it also privileges the role of specific people and techniques in the process of EM.

\section{LEAVE IT TO THE CORPORATE MANAGERS}

Once we accept that the environment needs to be managed, the EM literature leaves us with little doubt about who should be doing the managing: managers of larger corporations. According to Coddington (1993), "Most environmentalists realize that while they can continue to win environmental battles, only business can win the war. In essence, the ecological fate of the world is in the hands of industry" (p. 51). Elkington (1994) assures us that even environmentalists have come to recognize this:

In contrast to the anti-industry, anti-profit, and anti-growth orientation of much early environmentalism, it has become increasingly clear that business must play a central role in achieving the goals of sustainable development strategies. ${ }^{8}$ (p. 91)

Two assumptions underlie the proposition that EM be left to corporate managers. One is that managers have seen the environmental light; they are eager to address environmental problems because they are concerned citizens like the rest of us and because they take their responsibilities to all their stakeholders seriously (e.g., Elkington, 1994; Friedman, 1993). The tendency to universalize managerial interests has been noted by Alvesson (1991), who concluded from a study of management literature that 
The questions formulated and answered, the perspective taken, the sectional interests supported etc. are grounded in a world view, a set of beliefs and values, which indicate that the top managers of corporations and other organizations are a highly important group, whose actions are normally supposed to support the social good (whatever that might be). (p. 217)

A second assumption is that corporations possess the superior technical, financial, and organizational resources needed to solve environmental problems (Shrivastava, 1995b). According to Schmidheiny (1992), "Given the large technological and productive capacity of business, any progress toward sustainable development requires its active leadership" (p. 9). By implication, government is considered ineffective and inefficient in dealing with these issues.

Although corporations clearly do possess substantial resources, it does not necessarily follow that they should have primary responsibility for solving environmental problems. Mere possession of these resources should not insulate corporations from social and political mechanisms to oversee their direction and application. Moreover, the resource argument tends to legitimize the existing distribution of resources and precludes discussion of allocating more resources toward other forms of organization, such as universities, nonprofit organizations, and governmental agencies. Many of these organizations already have significant technical and organizational capabilities without the conflicts of interest faced by businesses under competitive pressure.

Further buttressing the primacy of corporate managers as environmental caretakers, the EM literature promotes the concept of stewardship to connote the wise, benevolent management and care of the environment by corporate stewards on behalf of the public. The unilateral assertion of stewardship sidesteps the question of who entrusted the environment to private hands and circumvents a consideration of corporate accountability. Stewardship operates in tandem with stakeholder theory (Freeman, 1984) to suggest that managers can balance the needs and interests of owners, employees, consumers, and the broader public in making decisions about the environment, while reserving to themselves exclusive decision-making power. The discourse of stewardship, although cloaked in a mask of neutrality, is actually quite paternalistic with feudal and antidemocratic overtones.

\section{EM IS A WIN-WIN OPPORTUNITY}

In case some of us remain unconvinced that business is sincere in its conversion to environmentalist values, the EM literature presents us with the ultimate reason why we should trust private profit-seeking firms to solve environmental problems: It is in their own best interests to do so-the optimistic win-win scenario. The assumption that EM can add value to a company plays a central role in providing legitimacy for corporate stewardship of the natural environment and for EM as an area of management research and practice. Friedman (1993) stresses the importance of win-win:

This book has one overriding theme: Good environmental management techniques benefit everyone. They help protect the environment. They make managers' jobs easier. They even save companies money, although some of these savings may not appear in the short term. (p. 7) 
Kinlaw (1993) reveals the theme of his book in the title Competitive and Green. Elkington (1994) calls it "win-win-win," although the third winner is unidentified. Part of the argument is that growing consumer concern for the environment will generate new, profitable markets for environmentally safer products. "Let's start with the most important point about green products: they represent a substantial product opportunity" (Coddington, 1993, p. 148). On the production side, people have drawn from the ideas of total quality and lean production to suggest that cutting pollution at its source rather than "at the end of the tailpipe" is likely to save money on raw materials, storage, and disposal costs (Bringer \& Benforado, 1994; Dielman \& deHoo, 1993; Shrivastava \& Hart, 1992). The strategic advantages of preempting the competition in environment-oriented innovation, cost reduction, and securing a positive public image have been emphasized by a number of writers (Hart, 1995; Porter, 1991; Shrivastava, 1995b).

It has already been noted that the win-win argument is not uncontested in the EM literature, although this does not seem to be a barrier to its mantra-like repetition. The appeal of the win-win position appears to be based more on ideology than on empirical evidence. The very words "win-win" assert the universalization of corporate interests and avert deeper questions about potential structural conflicts between profit maximization and environmental goals. The win-win position fits comfortably within and draws credibility from the broader discourse that social responsibility is good for business - most proponents add the proviso "in the long run," which makes the proposition somewhat difficult to test. The win-win argument also provides a case against government regulation, as corporations would be expected to pursue these profit opportunities themselves, without mandatory controls. This discourse has been embraced by U.S. regulatory agencies such as the EPA and the Department of Energy to justify their increasing reliance on voluntary programs (e.g., EPA, 1995; U.S. Department of Energy, 1995).

\section{USE THE TRADITIONAL MANAGEMENT TOOLS}

If the environment is to be managed, how should the task be accomplished? An examination of the rapidly growing body of courses, texts, and articles on EM suggests that the existing disciplines of management are readily adaptable to the task. There are a host of new texts on environmental marketing, accounting, production, and strategy (e.g., Piasecki, 1995; Rubenstein, 1994). Coddington (1993), for example, applies all the traditional marketing tools, such as segmentation, market research, and focus groups, to the greening project. Business schools are busy setting up new courses with titles such as Environmental Marketing and Environmental Issues in Production and Operations Management.

It is hardly surprising that management scholars bring preexisting theories and practices to bear on environmental issues, despite the limitations to these approaches discussed earlier. We have to be concerned that reliance on the existing managerial frameworks might constrain theoretical and empirical development and create overconfidence in managerial/technical solutions. Shrivastava (1995a) has observed that the traditional management paradigm is limited in its application to environmental issues due to its anthropocentric focus on production, consumption, and efficiency. Moreover, the focus on business or product-level issues can obscure the need for social and political mechanisms to address the complex organizationenvironment interface.

The application of existing managerial tools has clear ideological import in that it promotes the interests of corporate managers and management scholars; it 
buttresses the claim that managers can and should be entrusted with managing the environment and opens a hot new niche market for business schools to fill. In recent years, critical scholarship has explored the processes by which management disciplines themselves embody ideologies that privilege and universalize corporate interests under the mask of neutral technique (e.g., Alvesson \& Willmott, 1992; Clegg, 1990; Deetz, 1992). Most scholars of management, especially those located in business schools, have been trained to see the world through the eyes of senior corporate managers and tend to view corporate employers as the customer for their product, the students. This institutional context is increasingly reinforced by a reliance on corporate sources of funding (Soley, 1995) ${ }^{9}$ Business school academics are in jeopardy of acting as Gramsci's (1988) "organic intellectuals," unwittingly propagating theories and practices that support particular interests.

\section{CONCLUSION}

EM can be understood in the context of intensifying public concern over environmental problems and an associated increase in institutional pressures on corporations to improve their environmental performance. These pressures, which have spurred the growth of international regulatory regimes, national environmental bureaucracies, and nongovernmental environmental organizations, present a potential threat to the autonomy and market position of leading companies in Western industrialized economies. Just as business acquiescence to the New Deal expansion of the American welfare regulatory state can be viewed as an accommodation to the pressures created in the depression of the 1930s, EM can be seen as a material and ideological response to an impending environmental crisis. The material, practical aspects of EM are not mere cynical greenwashing; there is a limit to the extent to which ideology can paper over the gaps between the rhetoric of EM and public environmental concerns. EM has proven quite successful at identifying profitable opportunities for reducing toxic emissions and resource use and stimulating innovation of alternative products and processes. Although EM does not lead to Bookchin's (1986) self-sufficient bioregional communities, it does operate to reduce environmental hazards to a politically tolerable level.

Simultaneously, EM functions on an ideological level to legitimize the role of corporate management as stewards of the environment, deflecting the threat of more radical change to the economic and social system. EM is thus part of a process of temporary accommodation and compromise that entails shifting alliances within the hegemonic coalition, as business develops cooperative relationships with government agencies, the scientific community, and mainstream environmental organizations. It is important to acknowledge that many groups remain marginalized in the new environmental world order. No compromise or accommodation is required with politically weak groups, such as the poor and unemployed, less developed countries, future generations, or radical environmentalists. As a result, the distribution of environmental costs and benefits tends to be skewed to the advantage of relatively powerful groups (Bullard, 1993).

Nevertheless, the process of accommodation and compromise provides space and agency for environmentalist groups to pursue their goals in a Gramscian war of position, in which a dynamic kaleidoscope of shifting coalitions, ideologies, and market positions occasionally presents windows of opportunity. For example, the recognition of physical limits to resource use and waste disposal and the acknowledgment of the need to adjust prices to deal with environmental externalities (Cairncross, 1991; Stavins, 1989) can be viewed as ideological concessions that 
legitimize a new environmental discourse and shift the ground rules of public debate. Once firms begin estimating and reporting the full environmental costs of their products, the imposition of green taxes becomes harder to resist. Similarly, environmental organizations can try to use partnerships with corporations to gain resources, information, and access to important decision makers. However cynically it is used by some, the EM discourse of stakeholders and sustainability raises expectations that companies will deal with environmental problems seriously and creates external pressures to conform to their commitments. Similarly, corporations cannot embrace EM without legitimizing and strengthening the voices of managers and workers inside organizations who are concerned about environmental issues.

The EM paradigm falls into the perspective that Egri and Pinfield (1996) label reform environmentalism, clearly disappointing those environmentalists who advocate a more fundamental shift in society's values, culture, and structure. Indeed, EM imposes a form of discursive closure; left unchallenged are the cultural and ideological foundations of the economic system, which include competitive individualism, the idealization of affluence and consumption, the dominance of a utilitarian technical rationality over aesthetic or ethical values, and confidence in scientific progress and economic growth. Although "exploration of the topic of organizations and the biosphere requires a holistic approach that is multi-faceted, cross-disciplinary, and controversial" (Egri \& Pinfield, 1996, p. 459), EM inhibits a broader debate over economic goals, organizational governance mechanisms, and alternative approaches to addressing environmental problems.

\section{NOTES}

1. Gramsci described a war of position as a long-range strategy by counterhegemonic forces to build up the social, political, material, and ideological forces needed to achieve social change in Western democracies with strong civil societies. See Cox (1983).

2. There is, of course, a large literature in sociology and political science on the nature of ruling coalitions and their relationship to the state. See, for example, Bowman (1996), Dahl (1961), Domhoff (1990), Epstein (1969), and Mills (1967). The argument made here assumes that state agencies do have some autonomy. Divisions in U.S. state policy concerning climate change have been discussed by Hecht and Tirpak (1995).

3. Habermas (1984b, p. 14l) briefly mentions the possibility of an ecological crisis, but not in the specific context of capitalist relations of production. For an exposition of Habermas's concept of a legitimacy crisis, see Nielsen (1990).

4. Cook (1996) has attributed the relatively smooth phase-out of CFCs in the United States to the combination of a stiff tax, a flexible permit trading system, and a firm phase-out date.

5. Baudrillard (1983a, p. 27), however, argued that symbolic production is actually more expensive than the production of physical objects.

6. See Baudrillard (1987), particularly p. 51.

7. These rankings do, however, have more subjective components that leave them susceptible to symbolic manipulation.

8. Buchholz (1993, p. 2) is even more specific, arguing that line managers rather than top managers or staff should be given this responsibility.

9. The Buchholz (1993) text was funded in part by a joint effort of the National Wildlife Fund and the Corporate Conservation Council, a group of 15 companies including Dow, 3M, and Dupont. The Management Institute for Environment and Business, a U.S. organization supporting the development of curriculum materials for EM courses, has a list of corporate funders that includes Philip Morris, WMX Technologies, International Paper, Phillips Petroleum, and Amoco. 


\section{REFERENCES}

Akard, P. J. (1992). Corporate mobilization and political power: The transformation of U.S. economic policy in the 1970s. American Sociological Review, 57, 597-615.

Alvesson, M. (1991). Organizational symbolism and ideology. Journal of Management Studies, 28, 207-226.

Alvesson, M., \& Willmott, H. (Eds.). (1992). Critical management studies. Newbury Park, CA: Sage.

Ashford, N. A. (1993). Understanding technological responses of industrial firms to environmental problems: Implications for government policy. In K. Fischer \& J. Schot (Eds.), Environmental strategies for industry. Washington DC: Island.

Balikov, H. R., \& Cavanaugh, P. O. (1996). What we need to know about ISO 1400. Natural Resources and the Environment, 10(4), 64-72.

Baudrillard, J. (1983a). In the shadow of the silent majorities. New York: Semiotext.

Baudrillard, J. (1983b). Simulations. New York: Semiotext.

Baudrillard, J. (1987). Forget Foucault. New York: Semiotext.

Birchard, W. H. (1994, January). Tree-hugging takes root in B-schools. ECO, pp. 67-69.

Boehmer-Christiansen, S. A. (1995). Britain and the International Panel on Climate Change: The impacts of scientific advice on global warming: Part II: The domestic story of the British response to climate change. Environmental Politics, 4(2), 175-196.

Bookchin, M. (1986). The modern crisis. Philadelphia: New Society.

Bowman, S. R. (1996). The modern corporation and American political thought. University Park: Pennsylvania State University Press.

Bringer, R. P., \& Benforado, D. M. (1994). Pollution prevention and total quality environmental management. In R. V. Kolluro (Ed.), Environmental strategies handbook. New York: McGraw-Hill.

Buchholz, R. A. (1993). Principles of environmental management. Englewood Cliffs, NJ: Prentice Hall.

Bullard, R. D. (Ed.). (1993). Confronting environmental racism. Boston: South End.

Cairncross, F. (1991). Costing the earth. Cambridge, MA: Harvard Business School Press.

Carson, R. (1962). Silent spring. New York: Houghton Mifflin.

Cebon, P. B. (1993). The myth of best practices: The context dependence of two highperforming waste reduction programs. In K. Fischer \& J. Schot (Eds.), Environmental strategies for industry. Washington, DC: Island.

Clair, J. A., Milliman, J., \& Whelan, K. S. (1996). Toward an environmentally sensitive ecophilosophy for business management. Industrial and Environmental Crisis Quarterly, 9, 289-326.

Clawson, D., Neustadtl, A., \& Scott, D. (1992). Money talks: Corporate PACs and political influence. New York: Basic Books.

Clegg, S. (1990). Modern organisations: Organisation studies in the postmodern world. London: Sage.

Coddington, W. (1993). Environmental marketing. New York: McGraw-Hill.

Consumers Union. (1995). Captive kids: A report on commercial pressures on kids at school. New York: Consumers Union.

Cook, E. (1996). Marking a milestone in ozone protection: Leaming from the CFC phase-out. Washington, DC: World Resources Institute.

Cox, R. W. (1983, Summer). Gramsci, hegemony and international relations: An essay in method. Millennium, Joumal of International Studies, pp. 162-175.

Dadd, D. L., \& Carothers, A. (1991). A bill of goods? Green consuming in perspective. In C. Plant \& J. Plant (Eds.), Green business: Hope or hoax. Philadelphia: New Society.

Dahl, R. (1961). Who governs? New Haven, CT: Yale University Press.

Daly, H. E., \& Cobb, J. B. (1989). For the common good: Redirecting the economy toward community, the environment, and a sustainable future. Boston: Beacon.

Deetz, S. (1992). Democracy in an age of corporate colonization. Albany: State University of New York Press. 
Devall, B., \& Sessions, G. (1985). Deep ecology: Living as if nature mattered. Salt Lake City: Peregrine Smith.

Dickson, D. (1984). The new politics of science. New York: Pantheon.

Dielman, H., \& deHoo, S. (1993). Toward a tailor-made process of pollution prevention and cleaner production: Results and implications of the PRISMA project. In K. Fischer \& J. Schot (Eds.), Environmental strategies for industry. Washington, DC: Island.

Dillon, P. S., \& Fischer, K. (1992). Environmental management in corporations: Methods and motivations. Medford, MA: Center for Environmental Management, Tufts University.

Domhoff, G. W. (1990). The power elite and the state: How policy is made in America. New York: Aldine de Gruyter.

Donahue, J. (1990, March). Environmental board games. Multinational Monitor, pp. 10-13.

Dowie, M. (1995). Losing ground: American environmentalism at the close of the twentieth century. Cambridge, MA: MIT Press.

Doyle, J. (1991). Hold the applause! A case study of corporate environmentalism as practiced at DuPont. Washington, DC: Friends of the Earth.

Egri, C. P., \& Pinfield, L. (1996). Organizations and the biosphere: Ecologies and environments. In S. R. Clegg, C. Hardy, \& W. Nord (Eds.), Handbook of organization studies. Newbury Park, CA: Sage.

Ehrlich, P. R., \& Ehrlich, A. H. (1996). Betrayal of science and reason. Washington, DC: Island.

Elkington, J. (1994). Towards the sustainable corporation: Win-win-win business strategies for sustainable development. California Management Review, 36(2), 90-100.

Entine, J. (1995). The messy reality of socially responsible business. At Work, 4(3), 1-11.

Environmental Protection Agency (EPA). (1995). EPA's 33/50 program sixth progress update. Washington, DC: Author.

Epstein, E. (1969). The corporation in American politics. Englewood Cliffs, NJ: Prentice Hall.

Ewen, S. (1988). All consuming images. New York: Basic Books.

Fischer, K., \& Schot, J. (Eds.). (1993). Environmental strategies for industry. Washington, DC: Island.

Freeman, R. E. (1984). Strategic management: A stakeholder approach. Boston: Pitman.

Friedman, F. B. (1993). Practical guide to environmental management. Washington, DC: Environmental Law Institute.

Gelbspan, R. (1995, December). The heat is on. Harper's, pp. 31-40.

Getz, K. A. (1993). Corporate political tactics in a principal-agent context: An investigation in ozone protection policy. Research in Corporate Social Performance and Policy, 14, 19-55.

Gill, S. (1990). American hegemony and the Trilateral Commission. Cambridge, UK: Cambridge University Press.

Gladwin, T. N. (1993). The meaning of greening: A plea for organizational theory. In K. Fischer \& J. Schot (Eds.), Environmental strategies for industry. Washington, DC: Island.

Gladwin, T. N., Kennelly, J. J., \& Krause, T. (1995). Shifting paradigms for sustainable development: Implications for management theory and research. Academy of Management Review, 20, 874-907.

Gramsci, A. (1988). An Antonio Gramsci reader (D. Forgacs, Ed.). New York: Schocken.

Haas, P. M., Keohane, R. O., \& Levy, M. A. (Eds.) (1993). Institutions for the earth: Sources of effective international environmental protection. Cambridge, MA: MIT Press.

Habermas, J. (1976). Legitimation crisis. Boston: Beacon.

Habermas, J. (1984a). The theory of communicative action. Boston: Beacon.

Habermas, J. (1984b). What does a legitimation crisis mean today? In W. Connolly (Ed.), Legitimacy and the state. Oxford, UK: Basil Blackwell. 
Hansen, M. W. (1995). Theories of transnational corporations, environment and development. Working Paper No. 5, Copenhagen Business School, Department of Communication and Management.

Hansen, M. W., \& Gleckman, H. R. (1994). Environmental management of multinationals and transnational corporations: Policies, practices, and recommendations. In R. V. Kolluro (Ed.), Environmental strategies handbook. New York: McGraw-Hill.

Harrison, E. B. (1993). Going green: How to communicate your company's environmental commitment. Homewood, IL: Business One/Irwin.

Hart, S. L. (1994). How green production might sustain the world. Journal of the Northwest Environment, 10, 4-14.

Hart, S. L. (1995). A natural-resource-based view of the firm. Academy of Management Review, 20, 986-1015.

Hart, S. L., \& Ahuja, G. (1996). Does it pay to be green? Business Strategy and the Environment, 5, 30-37.

Hecht, A. D., \& Tirpak, D. (1995). Framework agreement on climate change: A scientific and policy history. Climatic Change, 29, 371-402.

Helvarg, D. (1994). The war against the greens. San Francisco: Sierra Club Books.

Hoffman, A. J. (1996, August). From heresy to dogma: Corporate greening as an instance of dynamic isomorphism. Paper presented at the Academy of Management meeting, Cincinnati, $\mathrm{OH}$.

Hunt, C., \& Auster, E. (1990). Proactive environmental management. Sloan Management Review, 31(2), 7-18.

Ikwue, T., \& Skea, J. (1994). Business and the genesis of the European Community carbon tax proposal. Business Strategy and the Environment, 3, 1-10.

Intergovernmental Panel on Climate Change. (1995). Second assessment report of the intergovernmental panel on climate change. Geneva: United Nations.

Jennings, P. D., \& Zandbergen, P. A. (1995). Ecologically sustainable organizations: An institutional approach. Academy of Management Review, 20, 1015-1052.

Kinlaw, D. C. (1993). Competitive and green. San Diego, CA: Pfeiffer.

Knights, D., \& Morgan, G. (1991). Corporate strategy, organizations, and subjectivity: A critique. Organisation Studies, 12(2), 251-273.

Lehne, R. (1993). Industry and politics. Englewood Cliffs, NJ: Prentice Hall.

Levy, D. L. (1994). Chaos theory and strategy: Theory, application, and managerial implications. Strategic Management Journal, 15, 167-178.

Levy, D. L. (1995). The environmental practices and performance of transnational corporations. Transnational Corporations, 4(1), 44-68.

Lovelock, J. (1988). The ages of Gaia: A biography of our living earth. New York: W. W. Norton.

Luke, T. W. (1991). Power and politics in hyperreality: The critical project of Jean Baudrillard. Social Science Journal, 28, 347-367.

Luke, T. W. (1995). Between democratic populists and bureaucratic greens: The limits of liberal democratic responses to the environmental crisis. Current Perspectives in Social Theory, 15, 245-274.

Mahon, J. F., \& Kelley, P. C. (1990). The politics of toxic waste: Multinational corporations as facilitators of transnational public policy. In L. E. Preston (Ed.), International and comparative corporation and society research. Greenwich, CT: JAI.

Mansley, M. (1995). Long term financial risks to the carbon fuel industry from climate change. London: Delphi Group.

McKibben, B. (1989). The end of nature. New York: Random House.

Merchant, C. (1992). Radical ecology. New York: Routledge.

Mills, C. W. (1967). The power elite. New York: Oxford University Press.

Morgan, G. (1992). Marketing discourse and practice: Towards a critical analysis. In M. Alvesson \& H. Willmott (Eds.), Critical management studies. Newbury Park, CA: Sage. 
Naess, A. (1989). Ecology, community, and lifestyle. Cambridge, UK: Cambridge University Press.

Nielsen, K. (1990). Legitimation in complex societies: Some Habermasian themes. Annals of Scholarship, 7(1), 51-89.

O'Connor, J. (1989). Political economy and ecology of socialism and capitalism. Capitalism. Nature, Socialism, 3, 93-106.

Ozone Action. (1996). Distorting the debate: A case study of corporate greenwashing. Washington, DC: Author.

Parsons, H. (Ed.). (1977). Marx and Engels on ecology. Westport, CT: Greenwood.

Pepper, D. (1993). Eco-socialism. London: Routledge.

Piasecki, B. (1995). Corporate environmental strategy: The avalanche of change since Bhopal. New York: John Wiley.

Porter, M. E. (1991, April). America's green strategy. Scientific American, pp. 168-176.

Purser, R. E., Park, C., \& Montuori, A. (1995). Academy of Management Review, 20, 1053-1089.

Rappaport, A., \& Flaherty, M. F. (1992). Corporate responses to environmental challenges. New York: Quorum.

Rasanen, K., Merilainen, S., \& Lovio, R. (1995). Pioneering descriptions of corporate greening: Notes and doubts on the emerging discussion. Business Strategy and the Environment, 3(4), 9-16.

Rooney, C. (1993, Summer). Economics of pollution prevention: How waste reduction pays. Pollution Prevention Review, pp. 261-276.

Rothenberg, S., \& Maxwell, J. (1995). Industrial response to the banning of CFCs: Mapping the paths of technical change. Working Paper, MIT Sloan School of Management.

Rowell, A. (1996). Green backlash: Global subversion of the environment movement. London: Routledge.

Rowlands, I. H. (1995). The politics of global atmospheric change. Manchester: Manchester University Press.

Rubenstein, D. B. (1994). Environmental accounting for the sustainable corporation: Strategies and techniques. Westport, CT: Quorum Books.

Russo, M. V., \& Fouts, P. A. (in press). A resource-based perspective on corporate environmental performance and profitability. Academy of Management Journal.

Salleh, A. (1984). Deeper than deep ecology: The ecofeminist connection. Environmental Ethics, 6, 335-341.

Salleh, A. (1992). The ecofeminism/deep ecology debate: A reply to patriarchal reason. Environmental Ethics, 14, 195-216.

Sassoon, A. S. (1987). Gramsci's politics. London: Hutchinson.

Schmidheiny, S. (1992). Changing course. Cambridge, MA: MIT Press.

Schnaiberg, A., \& Gould, K. (1994). Environment and society: The enduring conflict. New York: St. Martin's.

Schot, J., \& Fischer, K. (1993). The greening of the industrial firm. In K. Fischer \& J. Schot (Eds.), Environmental strategies for industry. Washington, DC: Island.

Shrivastava, P. (1992). Corporate self-greenewal: Strategic responses to environmentalism. Business Strategy and the Environment, 1(3), 9-21.

Shrivastava, P. (1995a). Ecocentric management for a risk society. Academy of Management Review, 20, 118-137.

Shrivastava, P. (1995b). The role of corporations in achieving ecological sustainability. Academy of Management Review, 20, 936-960.

Shrivastava, P., \& Hart, S. (1992). Greening organizations. Academy of Management, Best Paper Proceedings, 52, 185-189.

Smart, B. (1992). Beyond compliance. Washington, DC: World Resources Institute.

Soley, L. C. (1995). Leasing the ivory tower: The corporate takeover of academia. Boston: South End. 
Starik, M., \& Rands, G. P. (1995). Weaving an integrated web: Multilevel and multisystem perspectives of ecologically sustainable organizations. Academy of Management Review, 20, 908-935.

Stauber, J. C., \& Rampton, S. (1995). Toxic sludge is good for you. Monroe, ME: Common Courage.

Stavins, R. N. (1989). Harnessing market forces to protect the environment. Environment, $3 I(1), 5-35$.

Stead, W. E., \& Stead, J. G. (1996). Management for a small planet: Strategic decision making and the environment (2nd ed.). Thousand Oaks, CA: Sage.

Steffy, B. D., \& Grimes, A. J. (1992). Personnel/organization psychology: A critique of the discipline. In M. Alvesson \& H. Willmott (Eds.), Critical management studies (pp. 181201). Newbury Park, CA: Sage.

Steingard, D. S., \& Fitzgibbons, D. E. (1993). A postmodern deconstruction of total quality management. Journal of Organizational Change Management, 6(5), 27-42.

Strelow, R. (1992). Corporate public relations in the green era. In T. F. Sullivan (Ed.), The greening of American business. Rockville, MD: Government Institutes.

Townley, B. (1993). Foucault, power/knowledge, and its relevance for human resource management. Academy of Management Review, 18, 518-545.

United Nations Transnational Corporations and Management Division. (1993). Environmental management in transnational corporations: Report of the benchmark corporate environmental survey. New York: United Nations.

U.S. Department of Energy. (1995). Energy partnerships program update. Washington, DC: Author.

Walley, N., \& Whitehead, B. (1994, May-June). It's not easy being green. Harvard Business Review, pp. 46-52.

White, A. (1993, July-September). Accounting for pollution prevention. EPA Journal, pp. 23-25.

White, A., Becker, M., \& Savage, D. (1993, Summer). Environmentally smart accounting: Using total cost assessment to advance pollution prevention. Pollution Prevention Review, pp. 247-259. 